\title{
ANALISIS RASIO KEUANGAN UNTUK MENGUKUR TINGKAT KESEHATAN KEUANGAN DI PT GARUDA INDONESIA (PERSERO) Tbk
}

\author{
Oleh: \\ Dhona Shahreza \\ Program Studi Pendidikan Ekonomi \\ Fakultas llmu Pendidikan dan Pengetahuan Sosial \\ Universitas Indraprasta PGRI \\ Email: \\ denzanoena@gmail.com
}

\begin{abstract}
ABSTRAK
Penelitian ini bertujuan untuk mengukur tingkat kesehatan keuangan PT Garuda Indonesia (Persero) Tbk dengan indikator rasio likuiditas, solvabilitas dan profitabilitas. Metode kuantitatif deskriptif dengan pendekatan studi kasus dilakukan dengan metode pengumpulan data berupa studi pustaka dan dokumentasi. Data keuangan diambil berasal dari laporan keuangan PT Garuda Indonesia (Persero) Tbk berupa Laporan Laba Rugi dan Neraca selama tahun 2011 sampai dengan 2014. Instrumen yang dikembangkan berupa rasio likuiditas, solvabilitas dan profitabilitas. Tingkat kesehatan diukur berdasarkan Keputusan Menteri BUMN No. 100/MBU/2002. Hasil penelitian menunjukkan keseluruhan indikator mengalami penurunan dan kondisi kesehatan keuangan PT Garuda Indonesia (Persero) Tbk tahun 2011 sampai 2013 berada pada level Kurang Sehat dengan predikat BB sedangkan tahun 2014 berada pada level tidak sehat dengan predikat CCC.

Kata Kunci: Rasio Likuiditas, Rasio Solvabilitas, Rasio Profitabilitas, Kep No.100/MBU/2002.
\end{abstract}




\section{A. PENDAHULUAN}

Kinerja keuangan suatu perusahaan dapat dillihat dari dari laporan keuangan perusahaan/badan usaha yang bersangkutan dan itu tercermin dari informasi balance sheet (neraca), income statement (laporan laba rugi) dan cash flow (laporan arus kas) serta hal-hal lain yang mendukung serta penguat penilaian financial performance tersebut (Fahmi, 2011).

Laporan keuangan merupakan salah satu alat yang digunakan untuk mengetahui kinerja keuangan perusahaan yang disusun pada setiap akhir periode yang berisi pertanggungjawaban keuangan secara keseluruhan. Dengan kata lain, laporan keuangan dapat dijadikan sebagai gambaran keuangan perusahaan dalam satu periode akuntansi (Inayah, 2011). Dengan adanya laporan keuangan, manajer perusahaan akan bekerja semaksimal mungkin agar kinerja keuangan dinilai baik (Sitepu, 2010) dalam Fahmi (2014).

Dalam menilai kinerja keuangan perusahaan, pihak analisis keuangan membutuhkan beberapa metode dan teknik sebagai tolak ukur dan standar penilaian. Tolak ukur yang umum digunakan adalah rasio atau indeks yang menghubungkan dua data keuangan yang satu dengan yang lainnya. Analisis dan interpretasi dari berbagai macam rasio dapat memberikan pandangan yang lebih baik tentang kondisi keuangan dan prestasi perusahaan berbanding dengan data keuangan yang tidak berbentuk rasio (Lukiana, 2013).

Rasio merupakan perbandingan antara jumlah yang satu dengan yang lainnya. Siegel dan Shim (1999) dalam Warga (2006) mengemukakan bahwa rasio merupakan hubungan antara satu jumlah dengan jumlah lainnya dimana perbandingan tersebut memberikan gambaran relatif tentang kondisi keuangan dan prestasi perusahaan.

Analisis rasio keuangan merupakan salah satu teknik analisis laporan keuangan yang menghubungkan dua data keuangan dengan membagi satu data dengan data lainnya. Bahkan, analisis rasio keuangan merupakan alat utama dalam menganalisis keuangan, karena analisis ini dapat digunakan untuk menjawab berbagai pertanyaan tentang keadaan keuangan perusahaan (Jumingan, 2006). Selain itu, analisis rasio keuangan dapat digunakan untuk memprediksi kondisi keuangan perusahaan di masa yang akan datang. Ini disebabkan melalui analisis rasio keuangan, manajer dapat memprediksi reaksi kreditor dan investor dalam memperkirakan bagaimana memperoleh kebutuhan dana, serta seberapa besar dana sanggup diperoleh.

Analisis rasio keuangan memiliki beberapa keunggulan, antara lain: a) merupakan angka-angka atau ikhtisar yang lebih mudah dibaca dan ditafsirkan; b) pengganti yang lebih sederhana dari informasi yang disajikan laporan keuangan yang sangat rinci dan rumit; c) mengetahui posisi perusahaan di tengah industri lain; d) bermanfaat untuk bahan dalam mengisi model-model pengambilan keputusan dan model prediksi (Z-score); e) menstandardisasi size perusahaan; f) lebih mudah memperbandingkan perusahaan dengan perusahaan lain atau melihat perkembangan perusahaan secara periodik atau time series; dan g) lebih mudah melihat tren perusahaan serta melakukan prediksi di masa yang akan datang (Harahap, 2011). 
Industri penerbangan nasional kini terus mengembangkan usahanya dan dituntut untuk terus memperbaiki kinerja mengingat persaingan yang semakin ketat dari para kompetitornya. Indonesia merupakan negara kepulauan sehingga transportasi udara menjadi salah satu transportasi utama yang dapat menghubungkan wilayah di Indonesia. PT Garuda Indonesia yang tetap mempertahankan eksistensinya sebagai perusahaan jasa penerbangan nasional Indonesia, terus berkembang, salah satunya dengan mencatatkan usahanya sebagai perusahaan go public pada tahun 2011 setelah menyelesaikan seluruh restrukturisasi utang perusahaan. Berlakunya perang tarif antara maskapai penerbangan yang kian marak belakangan ini, di mana maskapai berlomba-lomba menawarkan jasa berupa tiket dengan harga yang sangat murah atau dikenal sebagai Low cost courier, tidak serta merta menurunkan kualitas pelayanan kepada penumpang. Oleh sebab itu, di tengah maraknya persaingan maka kinerja keuangan berupa tingkat kesehatan keuangan harus selalu terjaga agar kepercayaan masyarakat tidak menurun.

Tulisan ini bertujuan untuk menilai tingkat kesehatan keuangan PT Garuda Indonesia Tbk dilihat dari analisis rasio keuangan berupa rasio likuiditas, solvabilitas dan profitabilitas.

\section{B. KAJIAN PUSTAKA}

\section{Klasifikasi Rasio Keuangan}

Sawir (2005) dalam Warga (2006) membagi rasio keuangan menjadi beberapa jenis, yaitu:

\section{Rasio Likuiditas}

Merupakan rasio yang menggambarkan kemampuan perusahaan dalam memenuhi kewajibannnya yang akan jatuh tempo. Rasio likuiditas yang umum digunakan adalah:

a. Rasio lancar (Current Ratio). Rasio ini dihitung dengan membagi aktiva lancar dengan utang lancar. Rasio lancar merupakan ukuran yang paling umum diggunakan untuk mentahui kesanggupan memenuhi kewajiban jangka pendek, karena rasio ini menunjukkan seberapa jauh tuntutan dari kreditor jangka pendek dipenuhi oleh aktiva yang diperkirakan menjadi uang tunai dalam periode yang sama dengan jatuh tempo hutang.

$$
\text { Rasio lancar }=\frac{\text { Aktiva lancar }}{\text { Utang lancar }}
$$

Rasio lancar yang rendah biasanya dianggap menunjukkan terjadinya masalah dalam likuiditas. Sebaliknya suatu perusahaan yang rasio lancarnya terlalu tinggi juga kurang bagus, karena menunjukkan banyaknya dana menganggur yang pada akhirnya dapat mengurangi kemampulabaan perusahaan. 
b. Rasio cepat (Quick Ratio). Rasio ini dihitung dengan mengurangkan persediaan dari aktiva lancar dan kemudian membagi hasilnya dengan utang lancar.

$$
\text { Rasio Cepat }=\frac{\text { Aktiva lancar }- \text { Persediaan }}{\text { Utang lancar }}
$$

Persediaan merupakan unsur aktiva lancar yang tingkat likuiditasnya rendah, sering mengalami fluktuasi harga, dan unsur aktiva lancar ini sering menimbulkan kerugian jika terjadi likuidasi. Jadi rasio cepat lebih baik dalam mengukur kemampuan suatu perusahaan alam memenuhi kewajiban jangka pendeknya. Rasio cepat yang umumnya dianggap baik adalah 1 (satu).

c. Rasio kas. Rasio ini digunakan untuk mengukur kemampuan perusahaan dalam membayar kewajiban jangka pendek yang akan segera atau harus dilunasi dengan uang kas tersedia dalam perusahaan

$$
\text { Rasio Kas }=\frac{\text { Kas }+ \text { Bank }+ \text { Sekuritas }}{\text { Utang lancar }}
$$

\section{Rasio Manajemen Utang}

Rasio leverage mengukur tingkat sovabilitas suatu perusahaan. Rasio ini menunjukkan kemampuan perusahaan memenuhi segala kewajiban finansialnya seandainya perusahaan pada saat dilikuidasi. Dengan demikian solvabilitas berarti kemampuan suatu perusahaan untuk membayar semua utang-utangnya, baik jangka panjang atau jangka pendek. Rasio leverage yang umum digunakan adalah:

a. Rasio utang. Rasio ini dihitung dengan membagi Total utang dengan Total aktiva. Rasio ini memberikan tolak ukur seberapa besar total aktiva yang dimiliki oleh perusahaan yang dibiayai melalui penggunaan utang.

$$
\text { Rasio Utang }=\frac{\text { Total Utang }}{\text { Total aktiva }}
$$

Rasio ini memperlihatkan proporsi antara kewajiban yang dimiliki dan seluruh kekayaan yang dimiliki. Semakin tinggi persentasenya, cenderung semakin besar risiko keuangannya bagi kreditor maupun pemegang saham.

b. Rasio laba terhadap Beban bunga (Times Interest Earned Ratio)

Rasio ini dihitung dengan membagi Laba Sebelum Pajak dan Bunga (EBIT) dengan beban bunga. 
Rasio Laba terhadap Beban Bunga $=\frac{\text { EBIT }}{\text { Beban bunga }}$

Rasio ini mengukur kemampuan pemenuhan kewajiban bunga tahunan dengan laba operasi (EBIT), sejauh mana laba operasi boleh turun tanpa menyebabkan keagalan dalam pemenuhan kewajiban membayar bunga pinjaman.

c. Rasio total modal sendiri terhadap total aset (TMS terhadap TA). Rasio yang digunakan untuk menunjukkan seberapa solvabel perusahaan dalam mengolah modalnya terhadap aset yang dimilikinya.

$$
\text { Rasio TMS terhadap TA }=\frac{\text { TMS }}{\mathrm{TA}}
$$

\section{Rasio Manajemen Aktiva}

Merupakan rasio yang mengukur sejauh mana efektivitas manajemen perusahaan dalam mengelola aset-asetnya. Artinya dalam hal ini adalah mengukur kemampuan manajemen perusahaan dalam mengelola persediaan bahan mentah, barang dalam proses, dan barang jadi serta kebijakan pemasaran. Rasio manajemen aktiva menganalisis hubungan antara laporan laba rugi, khususnya penjualan dengan unsur-unsur yang ada pada neraca, khususnya unsur-unsur aktiva. Rasio aktivitas ini diukur dengan instilah perputaran unsur-unsur yang dihubungkan dengan penjualan. Rasio yang umum digunakan adalah:

a. Rasio perputaran persediaan.

Rasio ini dihitung dengan membagi Harga Pokok Pejualan dengan Ratarata persediaan. sedangkan untuk menghitung periode rata-rata persediaan dihitung dengan membagi jumlah hari dalam setahunnya. Satu tahun dapat diasumsikan 360 hari atau 365 hari, kedua angka ini digunakan dalaam lingkup keuangan dan perbedaannya tidak akan mempengaruhi keputusan yang dihasilkan.

$$
\begin{aligned}
& \text { Rasio Perputaran Persediaan }=\frac{\text { Harga Pokok Penjualan }}{\text { Rata }- \text { rata persediaan }} \\
& \text { Periode rata }- \text { rata persediaan }=\frac{360 \text { hari }}{\text { Perputaran Persediaan }}
\end{aligned}
$$

Perputaran ini menunjukkan berapa kali jumlah persediaan barang dagang diganti atau dijual dalam satu periode. Apabila perputaran persediaan barang itu cepat, maka tidak ada masalah bagi perusahaan. Sebaliknya, apabila perputaran persediaan barang lambat, hal ini akan mengganggu kelangsungan hidup perusahaan. Karena untuk menyimpan barang tersebut akan memerlukan berbagai macam biaya dan kerugian yang mungkin 
timbul, misalnya biaya sewa gudang, biaya pemeliharaan, biaya bunga, biaya kebakaran, dan lain-lain.

b. Rasio perputaran piutang

Rasio ini dihitung dengan membagi penjualan dengan rata-rata piutang usaha.

$$
\begin{aligned}
& \text { Rasio Perputaran Piutang }=\frac{\text { Penjualan }}{\text { Piutang rata }- \text { rata }} \\
& \text { Periode rata }- \text { rata Piutang Usaha }=\frac{360 \text { hari }}{\text { Perputaran Piutang Usaha }}
\end{aligned}
$$

Apabila perusahaan menunjukkan perputaran piutang semakin tinggi, maka perusahaan tersebut mempunyai tingkat risiko yang baik. Oleh karena dana yang diinvestasikan dalam piutang itu rendah. Sebaiknya, kalau rasionya semakin rendah berarti dana yang diinvestasikan dalam piutang semakin tinggi. Hal ini disebabkan oleh bagian kredit dan penagihan bekerja tidak efektif, ada perubahan dalam kebijakan pemberian kredit kepada pelanggan.

Dengan menggunakan perputaran piutang dagang dapat pula dihitung waktu rata-rata pengumpulan piutang tersebut, yaitu dengan membagi jumlah hari dalam setahun, dianggap 360 hari, dengan tingkat perputaran piutang tersebut. Semakin besar hari penagihan piutang, semakin besar pula risiko piutang tak tertagih.

c. Rasio perputaran total aktiva

Rasio ini dihitung dengan membagi penjualan dengan rata-rata total aktiva.

$$
\text { Rasio Perputaran Total aktiva }=\frac{\text { Penjualan }}{\text { Rata }- \text { rata Total aktiva }}
$$

Rasio ini menunjukkan efektivitas penggunaan seluruh harta perusahaan dalam rangka menghasilkan penjualan atau menggambarkan berapa rupiah penjualan bersih dapat dihasilkan oleh setiap rupiah yang diinvestasikan dalam bentuk harta perusahaan. Jika perputarannya lambat, menunjukkan bahwa aktiva yang dimiliki terlalu besar dibandingkan dengan kemampuan untuk menjual.

\section{Rasio Profitabilitas}

Kemampulabaan merupakan hasil akhir bersih dari berbagai kebijakan dan keputusan manajemen. Rasio kemampulabaan akan memberikan jawaban akhir tentang efektivitas manajemen perusahaan, rasio ini memberi gambaran tentang efektivitas pengelolaan perusahaan. Rasio keuangan yang umum digunakan antara lain: 
a. Rasio Marjin Laba Bersih (Profit Margin on Sales Ratio)

Rasio ini dihitung dengan membagi Laba Bersih dengan Penjualan. Rasio ini mengukur laba bersih setelah pajak terhadap penjualan.

$$
\text { Rasio Marjin Laba Bersih }=\frac{\text { Laba bersih }}{\text { Penjualan }}
$$

b. Rasio Daya Laba Dasar

Rasio ini dihitung dengan membagi Laba Sebelum Pajak dan Biaya Bunga (EBIT) dengan total aktiva. Rasio menunjukkan kemampuan menghasilkan laba dari aktiva perusahaan, sebelum pengaruh pajak serta bunga. Rasio ini sangat berguna untuk membandingkan perusahaan dengan siatuasi pajak yang berbeda dan tingkat bunga yang berbeda.

$$
\text { Rasio Daya Laba Dasar }=\frac{\text { EBIT }}{\text { Total aktiva }}
$$

c. Rasio Pengembalian atas Total Aktiva atau ROA

ROA sering disamakan dengan ROI. Rasio ini dihitung dengan membagi laba bersih dengan Total aktiva. Rasio ini menunjukkan seberapa banyak laba bersih yang bisa diperoleh dari seluruh kekayaan yang dimiliki oleh perusahaan.

$$
\text { ROI }=\frac{\text { Laba bersih }}{\text { Total aktiva }}
$$

d. Rasio Pengembalian Atas Ekuitas atau ROE

Rasio ini dihitung dengan membagi Laba bersih dengan Ekuitas. Rasio ini memperlihatkan sejauh mana perusahaan mengelola modal sendiri secara efektif, mengukur tingkat keuntungan dari investasi yang telah dilakukan oleh pemilik modal sendiri atau pemegang saham perusahaan.

$$
\mathrm{ROE}=\frac{\text { Laba bersih }}{\text { Ekuitas }}
$$

\section{Tingkat Kesehatan Keuangan}

Tingkat kesehatan perusahaan diperlukan untuk melihat apakah kondisi keuangan dalam suatu perusahaan itu dalam keadaan sehat atau tidak. Hal itu dapat dilakukan dengan membandingkan antara dua elemen yang ada atau disebut dengan rasio (Inayah, 2011).

Penggolongan tingkat kesehatan BUMN telah diatur oleh pemerintah melalui Surat Keputusan Menteri BUMN Nomor: KEP-100/MBU/2002 dengan rincian sebagai berikut (Inayah, 2011): 
a. Sehat yang terdiri dari:

1) AAA apabila total skor (TS) lebih besar dari 95;

2) AA apabila $80<\mathrm{TS} \leq 95$;

3) A apabila $65<\mathrm{TS} \leq 80$

b. Kurang Sehat yang terdiri dari:

1) BBB apabila $50<\mathrm{TS} \leq 65$

2) BB apabila $40<\mathrm{TS} \leq 50$

3) B apabila $30<\mathrm{TS} \leq 40$

c. Tidak sehat yang terdiri dari:

1) $\mathrm{CCC}$ apabila $20<\mathrm{TS} \leq 30$

2) $\mathrm{CC}$ apabila $10<\mathrm{TS} \leq 20$

3) $\mathrm{C}$ apabila $\mathrm{TS}<10$

\section{Tata Cara Penilaian Kesehatan BUMN}

Penilaian tingkat kesehatan perusahaan jasa sesuai dengan Surat Keputusan Menteri BUMN Nomor: KEP-100/MBU/2002 dalam Inayah (2011) adalah sebagai berikut:

Tabel 1.

Daftar Indikator dan Bobot Aspek Keuangan Perusahaan Jasa

\begin{tabular}{ccc}
\hline NO & INDIKATOR & BOBOT \\
\hline 1 & Imbalan kepada Pemegang Saham (ROE) & 20 \\
2 & Imbalan Investasi (ROI) & 15 \\
3 & Rasio Kas & 5 \\
4 & Rasio Lancar & 5 \\
5 & Rasio Modal Sendiri Terhadap Total Aset & 10 \\
& Total Bobot & 55 \\
\cline { 2 - 3 } Sumber: Surat Keputusan Menteri BUMN Nomor: KEP-100/MBU/2002 (Inayah,2011)
\end{tabular}

\section{METODE PENELITIAN} berikut:

Jenis dan metode yang dikembangkan dalam penelitian ini adalah sebagai

1. Penelitian deskriptif adalah suatu penelitian yang bertujuan untuk mengumpulkan data, dimana data yang telah berhasil dikumpulkan kemudian disajikan kembali dengan disertai analisis sehingga dapat memberikan gambaran yang jelas

2. Metode penelitian studi kasus adalah metode penelitian yang menjelaskan secara sistematis, faktual, dan akurat mengenai fakta dan karakteristik yang terjadi pada objek. Penelitian ini mempunyai ciri menjelaskan situasi atau kejadian dengan mencari informasi faktual, mengidentifikasi masalah dan 
praktek yang sedang berlangsung, kemudian membuat perbandingan dan evaluasi.

Teknik pengumpulan data yang dilakukan dalam penelitian ini adalah sebagai berikut:

1. Studi Pustaka, yaitu melakukan telaah, eksplorasi, dan mengkaji berbagai literatur pustaka yang relevan dengan penelitian

2. Dokumentasi, yaitu dengan mencari dan mengumpulkan data melalui laman web Bursa Efek Indonesia berupa laporan keuangan PT Garuda Indonesia Tbk selama tahun 2011 sampai dengan 2014.

Metode yang dikembangkan dalam penelitian ini adalah metode kuantitatif deskriptif, yaitu dengan memberikan gambaran tentang tingkat kesehatan keuangan perusahaan selama tahun 2011-2014 menggunakan perhitungan berupa analisis rasio keuangan. Pengolahan data dilakukan dengan menghubungkan teori yang sesuai dengan penelitian ini untuk kemudian ditarik kesimpulan tanpa melakukan ujian statistik dan pengujian hipotesis.

\section{HASIL DAN PEMBAHASAN}

\section{Analisis Rasio Keuangan}

Perhitungan rasio keuangan berasal dari laporan keuangan berupa laporan laba rugi dan Neraca PT Garuda Indonesia (Persero) Tbk selama tahun 2011 sampai dengan 2014. Berikut ini perhitungan rasio keuangan PT Garuda Indonesia (Persero) Tbk berserta entitas anak.

\section{Rasio Likuiditas}

Rasio Lancar

Tabel 2.

Perhitungan Rasio Lancar

\begin{tabular}{ccccc}
\hline TAHUN & $\begin{array}{c}\text { ASET LANCAR } \\
\text { (USD) }\end{array}$ & $\begin{array}{c}\text { KEWAJIBAN } \\
\text { LANCAR } \\
\text { (USD) }\end{array}$ & $\begin{array}{c}\text { RASIO } \\
(\mathbf{\%})\end{array}$ & SKOR \\
\hline 2011 & 757.266 .770 & 645.834 .604 & 117,25 & 4 \\
2012 & 636.566 .218 & 754.207 .052 & 84,40 & 0 \\
2013 & 836.522 .314 & 999.099 .449 & 83,73 & 0 \\
2014 & 810.514 .943 & 1.219 .365 .356 & 66,47 & 0 \\
\hline
\end{tabular}

Sumber: Data diolah (2015)

Tabel 2 menunjukkan pergerakan rasio lancar PT Garuda Indonesia (Persero) Tbk selama tahun 2011 sampai dengan 2014 mengalami penurunan. Tahun 2012 rasio lancar turun 32,85 poin dari tahun 2011. Rasio lancar tahun 2013 turun sebesar 0,67 poin sedangkan tahun 2014 turun 17,33 poin. Pada tahun 2011 skor 4 diberikan karena rasio lancar lebih dari 100\%. Sedangkan tahun 2012 sampai 2014 rasio lancar kurang dari 100\%. Oleh sebab itu skor tingkat kesehatan bagi indikator rasio lancar adalah nol. 


\section{Rasio Kas}

Tabel 3.

Perhitungan Rasio Kas

\begin{tabular}{ccccc}
\hline & KAS DAN SETARA & KEWAJIBAN & RASIO \\
TAHUN & KAS & (UAD) & (\%) & SKOR \\
& 417.252 .577 & 645.834 .604 & 64,61 & 5 \\
\hline 2011 & 325.784 .942 & 754.207 .052 & 43,20 & 5 \\
2012 & 480.429 .053 & 999.099 .449 & 48,09 & 5 \\
2013 & 434.327 .498 & 1.219 .365 .356 & 35,62 & 5 \\
2014 & & & & \\
\hline
\end{tabular}

Sumber: Data diolah (2015)

Perhitungan pada Tabel 3 menunjukkan bahwa rasio kas menurun setiap tahunnya. Rasio tahun 2012 turun sebesar 21,41 poin dari tahun 2011 yang sebesar 64,61\% menjadi 43,20\%. Pada tahun 2013 terjadi peningkatan sebesar 4,89 poin menjadi 48,09. Namun pada tahun 2014 kembali menurun cukup signifikan, yaitu sebesar 12,47 poin menjadi sebesar 35,62\%. Pemberian skor bagi indikator rasio kas adalah sebesar 5 karena rasio kas melebihi $35 \%$.

\section{Rasio Solvabilitas}

Tabel 4.

Perhitungan Rasio Solvabilitas

\begin{tabular}{ccccc}
\hline TAHUN & $\begin{array}{c}\text { TOTAL MODAL SENDIRI } \\
\text { (USD) }\end{array}$ & $\begin{array}{c}\text { TOTAL ASET } \\
\text { (USD) }\end{array}$ & $\begin{array}{c}\text { RASIO } \\
(\boldsymbol{\%})\end{array}$ & SKOR \\
\hline 2011 & 967.761 .161 & 2.127 .970 .194 & 45,48 & 9 \\
2012 & 1.114 .960 .078 & 2.517 .997 .766 & 44,28 & 9 \\
2013 & 1.125 .780 .064 & 2.992 .713 .206 & 37,62 & 10 \\
2014 & 916.712 .520 & 3.100 .815 .978 & 29,56 & 7,25 \\
\hline
\end{tabular}

Sumber: Data diolah (2015)

Rasio solvabilitas PT Garuda Indonesia (Persero) Tbk menunjukkan tren yang semakin menurun tiap tahunnya. Tahun 2012 menghasilkan nilai rasio $44,28 \%$ yang menurun sebesar 1,2 poin dari rasio tahun 2011 sebesar 45,48\% Pada tahun 2013 kembali turun menjadi 37,62\% atau sebesar 6,66 poin. Penurunan yang signifikan terjadi pada tahun 2014, yaitu sebesar 8,06 poin. Skor sebesar 9 diberikan pada tahun 2011 dan 2012 karena nilai rasio berada pada $40 \% \leq$ rasio $\leq 50 \%$. Rasio tahun 2013 mendapat skor 10 karena berada pada rentang $30 \% \leq$ rasio $\leq 40 \%$. Sedangkan tahun 2014 mendapat skor 7,25 karena rasio berada pada rentang $20 \% \leq$ rasio $\leq 30 \%$. 


\section{Rasio Profitabilitas}

ROE

Tabel 5.

Perhitungan ROE

\begin{tabular}{ccccc}
\hline TAHUN & $\begin{array}{c}\text { LABA SETELAH } \\
\text { PAJAK } \\
\text { (USD) }\end{array}$ & $\begin{array}{c}\text { MODAL SENDIRI } \\
\text { (USD) }\end{array}$ & $\begin{array}{c}\text { RASIO } \\
(\mathbf{\%})\end{array}$ & SKOR \\
\hline 2011 & 64.225 .536 & 967.761 .161 & 6,64 & 10 \\
2012 & 110.842 .573 & 1.114 .960 .078 & 9,94 & 14 \\
2013 & 13.583 .008 & 1.125 .780 .064 & 1,21 & 4 \\
2014 & $(371.974 .942)$ & 916.712 .520 & $-40,58$ & 0 \\
\hline
\end{tabular}

Sumber: Data diolah peneliti (2015)

Rasio ROE pada Tabel 5 menunjukkan angka rasio yang menurun, meskipun sempat terjadi kenaikan pada tahun 2013. Penurunan sangat signifikan terjadi pada tahun 2014 dimana nilai rasio mencapai kurang dari 0. Skor 10 diberikan pada tahun 2011 karena rasio pada tahun ini berada pada rentang $6,6 \leq \mathrm{ROE} \leq 7,9$. Pada tahun 2012 skor 14 diberikan karena rasio berada pada rentang $9 \leq \mathrm{ROE} \leq 11$. Pada tahun 2013 skor 4 diberikan karena rasio berada pada rentang $1 \leq \mathrm{ROE} \leq 2,5$. Rasio pada tahun 2014 adalah sebesar $-40,58 \%$ sehingga mendapatkan skor nol.

\section{ROI}

Perhitungan Rasio ROI dan pemberian skor ditunjukkan dengan tabel berikut ini.

Tabel 6.

Perhitungan ROI

\begin{tabular}{|c|c|c|c|c|}
\hline TAHUN & $\begin{array}{l}\text { LABA SETELAH PAJAK } \\
\text { (USD) }\end{array}$ & $\begin{array}{l}\text { TOTAL ASET } \\
\text { (USD) }\end{array}$ & $\begin{array}{c}\text { RASIO } \\
(\%)\end{array}$ & SKOR \\
\hline 2011 & 64.225 .536 & 2.127 .970 .194 & 3,02 & 4 \\
\hline 2012 & 110.842 .573 & 2.517.997.766 & 4,40 & 4 \\
\hline 2013 & 13.583 .008 & 2.992.713.206 & 0.45 & 2 \\
\hline 2014 & $(371.974 .942)$ & 3.100 .815 .978 & -12 & 1 \\
\hline
\end{tabular}

Rasio ROI sebagaimana ditunjukkan dengan Tabel 6 adalah menurun setiap tahunnya. Penurunan yang paling signifikan terjadi pada tahun 2014 dimana rasio mencapai nilai minus.

\section{Perhitungan Tingkat Kesehatan Keuangan}

Rasio dari keempat indikator tingkat kesehatan keuangan perusahaan dihitung, maka selanjutnya penentuan tingkat kesehatan dilakukan seperti tertera pada tabel di bawah ini. 
Tabel 7.

Penentuan Tingkat Kesehatan Keuangan

\begin{tabular}{ccccc}
\hline INDIKATOR & $\mathbf{2 0 1 1}$ & $\mathbf{2 0 1 2}$ & $\mathbf{2 0 1 3}$ & $\mathbf{2 0 1 4}$ \\
\hline Rasio Lancar & 4 & 0 & 0 & 0 \\
Rasio Kas & 5 & 5 & 5 & 5 \\
TMS terhadap TA & 9 & 9 & 10 & 7,25 \\
ROE & 10 & 14 & 4 & 0 \\
ROI & 4 & 4 & 2 & 1 \\
Total & 32 & 32 & 18,25 & 13,25 \\
Penambahan Skor & 15 & 15 & 15 & 15 \\
Total Skor & 47 & 47 & 36 & 28,25 \\
Kategori & BB & BB & B & CCC \\
& Kurang Sehat & Kurang Sehat & Kurang Sehat & Tidak Sehat \\
\hline \multicolumn{2}{c}{ Sumber: Data diolah (2015) } &
\end{tabular}

Berdasarkan tabel diatas, maka kondisi keuangan PT Garuda Indonesia (Persero) Tbk tahun 2011 sampai 2012 berada pada level BB (kurang sehat) sedangkan pada tahun 2013 berada pada level B (kurang sehat). Kondisi keuangan pada tahun 2014 adalah CCC (tidak sehat).

\section{Tren Rasio Likuiditas}

Rasio likuiditas bertujuan untuk mengukur kemampuan perusahaan dalam melunasi kewajiban jangka pendeknya, dimana semakin tinggi nilai rasio maka menunjukkan kondisi perusahaan yang semakin likuid. Penurunan yang terjadi selama tahun 2011 sampai dengan 2014 menunjukkan perusahaan berada dalam masalah likuiditas, di mana aset lancar tidak mampu memenuhi kewajiban lancarnya. Apabila dikaitkan dengan modal kerja perusahaan, maka PT Garuda Indonesia (Persero) Tbk tidak memiliki modal kerja yang cukup untuk membiayai kebutuhan operasionalnya. Ini terjadi karena modal yang ditanam ke dalam aktiva tidak lancar terlalu besar.

Tren yang ditunjukkan oleh rasio kas juga menurun meskipun dari skor mendapatkan poin 5 karena berada pada level lebih dari 35\%. Ini menunjukkan kondisi kecukupan kas perusahaan masih memadai.

\section{Tren Rasio Solvabilitas}

Rasio ini mengukur kemampuan perusahaan dalam memperoleh dana baru berasal dari sumber daya yang dimiliknya. Rasio solvabilitas menunjukkan tren yang semakin menurun. Tabel 3 menunjukkan jumlah modal yang dimiliki semakin berkurang sementara total aset bertambah setiap tahunnya. Ini menunjukkan masih tingginya jumlah modal bergerak perusahaan.

\section{Tren Rasio Profitabilitas}

Kemampuan perusahaan memperoleh laba yang berasal dari sumber daya yang dimiliki diukur menggunakan rasio profitabilitas. Rasio ini pula menunjukkan tren yang terus menuun setiap tahunnya. Penurunan disebabkan laba bersih yang didapat perusahaan terus menurun setiap tahunnya. Bahkan pada 
tahun 2014 perusahaan mengalami kerugian. Selain itu, penurunan ini disebabkan aktiva yang dimiliki perusahaan tidak mampu menghasilkan laba yang tinggi. Oleh sebab itu perusahaan perlu meningkatkan produktivitas dari aktiva dengan cara meningkatkan kegiatan operasionalnya.

\section{Tingkat Kesehatan Keuangan}

Secara keseluruhan kondisi keuangan PT Garuda Indonesia (Persero) Tbk berada pada level kurang sehat dan tidak sehat. Ini perlu diwaspadai mengingat perusahaan ini merupakan maskapai nasional sehingga tingkat kelangsungan usaha harus terus dijaga.

\section{E. SIMPULAN}

1. Keseluruhan indikator kesehatan keuangan PT Garuda Indonesia (Persero) Tbk, yang terdiri atas rasio likuiditas, rasio solvabilitas dan rasio profitabilitas menunjukkan tren yang menurun selama tahun 2011 sampai dengan 2014.

2. Kondisi kesehatan keuangan PT Garuda Indonesia (Persero) Tbk adalah kurang sehat pada tahun 2011 sampai 2013 dengan predikat BB dan dalam kondisi tidak sehat pada tahun 2014 dengan predikat CCC. 


\section{DAFTAR PUSTAKA}

Fahmi, Irham. (2011). Analisis Laporan Keuangan. Bandung: CV Alfabeta

Fahmi, Muhammad Febrian. (2014). Analisis Keuangan dan Hubungannya dengan Harga Saham pada Perusahaan PT. Garuda Indonesia. Skripsi yamg dipublikasikan. Diakses pada 26 Juli 2015.

Harahap, Sofyan Syafri. (2010). Analisis Kritis Atas Laporan Keuangan. Jakarta: PT Raja Grafindo Persada.

Harjito, Agus D., Martono. (2012). Manajemen Keuangan. Edisi ke-2. Yogyakarta: Ekonosia.

Ikatan Akuntan Indonesia. (2009). Pernyataan Standar Akuntansi Keuangan. Jakarta: Salemba Empat.

Inayah, Nur. (2011). Analisis Kinerja Keuangan Perusahaan Sebelum dan Sesudah Go Public (Studi Kasus pada PT. Jasa Marga Tbk.). Diakses pada 7 Agustus 2015.

Jumingan. (2006). Analisis Laporan Keuangan. Jakarta: Bumi Aksara.

Junita, Silvi., Khairani, Siti. (2013). Analisis Kinerja Perusahaan dengan Menggunakan Analisa Rasio Keuanga pada Perusahaan Telekomunikasi yang terdaftar di Bursa Efek Indonesia. Artikel yag dipublikasikan. Diakses tgl 7 Agustus 2015.

Kamaludin., Indriani, Rini. (2012). Manajemen Keuangan Konsep Dasar dan Penerapannya. Bandung: CV. Mandar Jaya. Cetakan ke-7

Kasmir. (2010). Analisis Laporan Keuangan. Jakarta: PT Rajagrafindo Persada. Cetakan ke-3

LSMAP. (2010). Pengertian Laporan Keuangan dan Analisis Laporan Keuangan. http://lsmap.wordpress.com/2010/03/01/penegertian-laporan-keuangan.

Diakses tgl 7 Agustus 2015

Lukiana, Ninik. (2013). Implementasi Rasio Keuangan untuk Menilai Kinerja Keuangan (Stusi Kasus pada PT. Lamicitra Nusantara Tbk Periode 20102012. Diakses pada 26 Januari 2015.

Munawir, Slamet. (2002). Analisa Laporan Keuangan. Yogyakarta: Liberty.

Prastowo, D Dwi., Julianty, Rifka. (2008). Analisis Laporan Keuangan: Konsep dan Aplikasi. Edisi kedua. Yogyakarta: UPP STIM YKPN

Sawir, Agnes. (2005). Analisis Kinerja Keuangan dan Perencanaan Keuangan Perusahaan. Jakarta: PT Gramedia Pustaka Utama. 
Surat Keputusan Menteri Badan Usaha Milik Negara Nomor: KEP100/MBU/2002 tentang Penilaian Tingkat Kesehatan Badan Usaha Milik Negara. 2002. Jakarta. Diakses pada 17 Agustus 2015.

Sutrisno. (2007). Manajemen Keuangan Teori Konsep dan Aplikasi. Yogyakarta: Ekonosia.

Warga, Poetri Mustika. (2006). Analisa Laporan Keuangan dan Indikator Kebangkrutan untuk Menilai Kinerja Keuangan serta Kelangsungan Usaha pada PT Mayora Indah Tbk beserta Anak Perusahaan Periode 2001-2005. Skripsi. Diakses tgl 26 Juli 2015

Warren J, Keegen. (2006). Manajemen Pemasaran Global Edisi Bahasa Indonesia. Jilid 2. Jakarta: PT Prenhalindo 